\title{
Whole Brain Teaching
}

\author{
Ms. Preslee D. Kharsati Dr. Prakasha G.S \\ Mphil research scholar \\ Assistant professorChrist UniversityBangalore
}

\begin{abstract}
Neuroscience in education aims to bridge the gap between the knowledge of how the brain works and how this knowledge can be applied in classroom practices. The main challenges for teachers is how do they translate that knowledge to classroom practices and what strategies should they adopt?. Chris Biffle and his colleagues came up with Whole Brain Teaching (WBT) method in 1999. It started off with one teacher problem in the classroom which leads to research and development of techniques that can activate the whole brain in learning. WBT is an approach which is surrounded by the seven core technique which is class yes-attention getter, the classroom rules- the organizer, hands and eyes which - the focuser, teach-Okay - the whole brain activator, mirror - the class unifier, switch - involver and finally the scoreboard - the motivator. Based on the practitioners of WBT it was found out that WBT has a positive influence on the academic achievement of students. WBT has made a huge difference in the way students remember and retain information, students are more engaged, their critical thinking is increased and students are actively participating inside the classrooms.
\end{abstract}

Key words: Neuroscience, Brain based learning, Whole Brain Teaching (WBT), Engagement, Classroom management

\section{INTRODUCTION}

Neuroscience is the empirical study of the brain and connected nervous system (The royal society, 2011). It also brings in the connection between biology, cognitive science and education to support better learning in schools (Jensen, 2005). Neuroscience has experience a rapid growth in education in its emerging effort to integrate neuroscience methods, particularly functional neuroimaging, with behavioural methods to address issues of learning and instruction (Varma, Candliss, Schwartz, 2008). It brings in the opportunity for teachers to understand about how we learn and about effective ways to teach (Jensen, 2005). Educators are looking forward to find out how neuroscience-informed education can emphasize their work to improve education (Jones, 2014). The brain is the organ that enables us to adapt to our environment-in essence, to learn. Neuroscience enables us to indentify key indicators for educational outcomes, and provides a scientific basic for evaluating different teaching approaches. Key findings based on neuroscience include the following

1. The brain is plastic. The brain keep on changing and whatever we do changes our brain. These changes can be short lived or long lasting. The brain is sometimes referred to as 'neuroplasticity' since it has an extraordinary adaptability.

2. The brain's response to rewards is influenced by expectations and uncertainty. Neuroscience research has revealed that there is a relationship between reward and learning in the context of reinforcement learning. It is this response of the reward system that allows us to learn which action has the most valuable outcome (The royal society, 2011).

3. Different individuals have different learning ability. Some individuals find difficult to learn in all domain, whereas others have specific learning difficulties like learning of language, numbers, and literacy.

4. Body movements increase blood flow and connectivity in the hippocampus, a key region for memory formation and consolidation (Jones, 2014)

5. The brain does and can grow new neurons. Neurons are highly correlated with memory, mood, and learning (Jensen, 2008).

Our brain is involved in everything we do and the daily experiences plays an important role in shaping our brain like learning a new song, learning how to solve a math problem, learning a new language or learning how to write. Research shows that change in our experiences results to change in our brain. This simply means that our brain is involved in everything we do and that our experiences has the ability to change our brain and therefore it is very important that the school provide a positive experience in learning to every child for effective learning to happen (Jensen, 2008). Brain research however has provided educators with better understanding of how our brain works and what strategies can they develop in order to help children learn. Brain based learning was able to make a connection between brain research and teaching practices ( Willis, 2007).

DOI: $10.9790 / 0837-2206027683 \quad$ www.iosrjournals.org $\quad 76 \mid$ Page




\section{BRAIN BASED LEARNING}

In 1983 Brain based learning was introduced where it established a relationship between how the brain functions and the educational practices. According to brain based learning, "In everything we do our brain is involved, let's learn more about it and apply that knowledge" (Jensen, 2005). Brain based learning is based on the theory that each brain is unique and that not all students learn in the same way and that everybody has the ability to learn (Duman, 2006; Tufekci \& Demirel, 2009). Advocates of brain-based learning have concluded that teaching techniques based on neuroscience of how the brain learns are effective in producing long term learning (Duman, 2006; Tufekci \& Demirel, 2009) and leads to successful academic achievement of the students (Duman, 2010; Duman, 2006; Inci, N \& Erten, H. 2009; Tufekci \& Demirel, 2009; Tufekci \& Demirel, 2009). Brain based learning is different from traditional method because it emphasizes on meaningful learning instead of memorization (Tufekci \& Demirel, 2009). When learning becomes meaningful students develop an interest in the subject and can perform better (Inci, N \& Erten, H. 2009; Tufekci \& Demirel, 2009). Brain based learning also helps to increase the recalling level of students (Inci, N \& Erten, H. 2009). Educators need to understand of how the brain function in order to produce interesting and relevant teaching styles (Dufford, 2004). The key to academic and vocational success is in understanding about how our brain works since students have their own learning preferences (Porter, 2007). New research also suggest that our brain is designed to forget but if educators makes teaching and learning fun in such a way that it will entertain and build in a positive interest in the child they are bound to hold on to such information (Serrao, 2007). There are countless ways in which schools affect students' brain, for example stress, exercise, nutrition, and social conditions and also brain-based issues like attention, classroom attendance and memory. The brain is involved in everything we do at school and to ignore it would be irresponsible (Jensen, 2005). Hence in 1999 a new method of teaching based on brain research was established by college philosophy instructor Chris Biffle, in Southern California known as the Whole Brain Teaching method (Biffle, 2010).

\section{WHOLE BRAIN TEACHING}

Whole brain teaching is based on the philosophy of teaching and learning that aims to maximize students' involvement by activating the whole brain in learning (Stearns, 2016) and is based on the principles of cooperative learning (Alford, 2014). Whole brain teaching emphasize active learning where the whole brain is involved in learning. Chris Biffle collaborates with two of his former students, Jay Vanderfin and Chris Rekstad to develop strategies to improve learning in classroom and hence Whole Brain Teaching emerge as a grassroots educational reform movement after 15 years of classroom application where they combine effective classroom management and pedagogically sound approaches to student engagement that are effective with a wide range of student learning populations (Battle, 2010). Whole brain teaching is also known as "Power teaching". It is considered as one of the world's fastest growing education reform movement (Biffle, 2010). It is an approach designed towards increasing student's involvement, and focusing on the way the brain is really designed to learn (Battle, 2010). Whole brain teaching focus in making learning fun, Biffle and his team believe that students learns best when educational activities are fun and not only that students learns but also such environment helps to decrease challenging behaviours inside the classroom (Biffle, 2013). Chris and his colleague found out that students are more engaged in class when they were emotionally involved in lessons that required students to see, to say, to hear and to move physically (Biffle, 2013). Whole brain teaching is a combination of direct instruction and collaborative learning (Whole brain teaching website). In whole brain teaching students are given the freedom to visualize, draw and act out their learning. It is a very flexible method which can be used for all age group from kindergarten students to college students. The philosophy of whole brain teaching can be best understood in four words: engagement, involvement, whole brain and principles. In order to make students and engaged in learning, whole brain teaching method is surrounded by seven fun-filled techniques known as The Big Seven.

\section{THE BIG SEVEN}

The philosophy of Whole brain teaching is surrounded by seven core techniques of teaching referred to as the Big Seven (Biffle, 2013). These seven step provides a collection of highly structured classroom, with a clearly laid out set of teaching strategies and routine classroom management that can be restructured, mixed, matched, and redesigned to fit individual teachers ( Heeter \& Efird, 2014). It also breaks learning down into small segments with direct instruction leading to cooperative learning and instant feedback.

Technique 1: Class-Yes: Attention Getter- In order to gain students attention, the teacher begins class with one word by saying "class" any way the teacher likes, and the students are responsible to mimic the teachers' 
voice by responding "Yes" (Battle, 2010; Tipton, 2016; Clark, 2016). In whole brain teaching classroom the teacher uses the attention getter before she/ he begins the class (Tipton, 2016). The attention getter activates the prefrontal cortex which is the brain boss. Learning will not be effective if the prefrontal cortex is not engaged. Class yes is like a readiness switch that prepares students for the days lesson (Biffle, 2013).

Technique 2: Classroom Rules: The Organizer- To begin with the informative part of the class lesson, the teacher utilized five classroom rules with the entire class that were rehearsed daily. Each rule corresponded to its own gesture and each rule is an intimate part of the classroom learning environment (Battle, 2010; Clark, 2016; Tipton 2016). The gestures activate the student's motor cortex which is considered as the brain most powerful area for memory retention and also most importantly these gestures makes learning rules entertaining and fun to practice which again helps in activating the limbic system (Biffle, 2013). The five classroom rules are as follows:

1. Follow directions quickly! (Make your hand shoot forward like fish)

2. Raise your hand for permission to speak (raise your hand, bring down to head and make a talking motion)

3. Raise your hand for permission to leave your seat (raise hand, make a walking motion with fingers).

4. Make smart choices!- Kindness, Courage, Invincible Grit, Creativity (tap one finger to your temple as you say each word).

5. Keep your dear teacher happy (hold up each thumb and index finger out like an "L" framing your face; bob your head back and forth with each word and smile really big!) ( Tipton, 2016)

- $\quad$ The Diamond rule: Keep your eyes on the target, Please (pointing your eyes with your index finger)

Technique 3: Hands and Eyes: The Focusor- When important point is needed to addressed to the students, the teacher said, "Hands and eyes" and the students will respond "Hands and eyes". This technique helps the teacher to get maximum attention from the students (Clark, 2016). This can be used whenever the teacher wants the students to pay extra attention (Tipton, 2016). Hands and eyes gives the teacher an instant silence and instant focussing by eliminating all learning distractions ( Biffle, 2013).

Technique 4: Teach- Okay: Whole brain activator: Once the teacher gets the student attention, the teacher engaged in direct verbal instruction using gestures to represent the lesson concepts (Clark, 2016). Teach-Okay gives students the opportunity to gain confidence and increases students' engagement (Cannon, 2014). Research indicates that students learn best when they are involved in teaching to each other (Biffle, 2013). So while students are teaching to each other, at the same time the teacher can check that all students participate and give them instant feedback (Battle, 2010). During teach okay five areas of the brain are activated like the visual cortex when students look and follow the teacher gestures, motor cortex when the students are making the gestures, Broca's area when the students start teaching to each other, Wernicke's area when the students listen to the teacher's teaching and the Limbic system when the students are showing their emotions to the lesson taught (Biffle, 2013).

Technique 5: Mirror: The class unifier: It is the simplest and most powerful technique. The teacher say "mirror" and the students will respond "mirror". Then the students will mimic both the speech and gestures of the teacher (Biffle, 2013; Tipton, 2016). As students imitate the teachers words and gestures, their motor cortex, the brain most reliable memory area, is automatically engaged (Biffle,2013). A number of research studies has also shown that accompanying words with gestures results in better memory (Jones, 2014) and also helps in better functioning of the brain where students are able to actively engaged in the learning activities (Davis, 2007).

Technique 6: Switch: The involver: Students should be encouraged to discuss and share their experience of what they have learned with each other in class ( Duman, 2010). Hence the next technique in WBT is called Switch. In WBT students teach their neighbours the instructor's lesson every minute or so (Biffle, 2013). The class is being divided between those of the Brocaians (the speakers) and the Wernikites (the listeners). One student will teach and the other will listen, the moment the teacher says "Switch" students response "Okay" the students exchange their role. This technique improves the listening skills of the speakers and speaking skills to the listeners ( Biffle, 2013).

Technique 7: The Scoreboard: The Motivator: To support attention and motivation in the classroom the teacher created the scoreboard. The purpose of the scoreboard is not to transform the behaviour of the students, 
but to unify as many students as possible behind the teacher's leadership (Biffle, 2013). The reward is the main motivator.

These are just a few technique of whole brain teaching that provide teachers with a method that integrates both effective, fun, low stress classroom management and exciting method that produce enhanced retention and comprehension content (Battle, 2010). These seven techniques have been tested in classroom for over 10 years. The feedback received from hundreds of teachers participating at conference, feedback from whole brain teaching website or via emails from across the country helps in refining these instructional strategies (Biffle, 2013).

\section{THEORIES BEHIND WHOLE BRAIN TEACHING}

The two theories that led to the development of whole brain teaching was Vygotsky's socio-cultural theory and the other is the Wenger's community of practice. The two theories are discussed below.

\section{Vygotsky's Sociocultural Theory}

Whole brain teaching method is based on the philosophy of socio-cultural theory introduced by a Russian psychologist Lev S. Vygotsky as he was trying to improve his teaching by studying learning and development. Vygotsky's socio cultural theory believed that human activities take place in cultural settings and cannot be understood apart from these settings. Peer interaction is the main factor of this theory. According to this theory, every child's cultural development appears twice: first, on the social level that is between people (inter-psychological) and later on the individual level that is inside the child (intra-psychological). The first level which is the social level is constructed during shared activities and it is considered as the higher mental processes where knowledge is constructed by teaching to each other. Then the later part where the child start to internalized the process it becomes part of the child's cognitive development (Woolfolk, 2008). Based on this theory, technique like Teach-Okay has been included in the big seven where students construct their knowledge by teaching to their partner and also to help the child personalized their learning the last step in of every whole brain teaching lesson plan is the advanced critical thinking where the child is given the opportunity to sum up the lesson in their own words.

\section{Wenger's community of practice}

According to Wikipedia community of practice was started by cognitive anthropologist Jean Lave together with an educational theorist Etienne Wenger in their book 'Situated learning' in 1991. Even though the term Wenger's community practice is termed recently but the phenomenon is old age as people has been sharing ideas and learns through story telling. The concept of this practice has provide useful perspective on knowing and learning. One of the major domains of Wenger's community of practice is the mutual engagement. In mutual engagement there involves a regular interaction and a constant flow of information (Homles \& Meyerhoff). This is the basic for making relationships and also it is the basic which makes community of practice possible.

Whole Brain Teaching combines the philosophy of both these theories that help in setting up of the Big Seven Technique. These seven step provides a collection of highly structured classroom, with a clearly laid out set of teaching strategies and routine classroom management that can be restructured, mixed, matched, and redesigned to fit individual teachers (Heeter \& Efird, 2014). These seven steps are not prescribed lesson plan but it is an approach to teaching which integrate fun learning activities into teaching. It also breaks learning down into small segments with direct instruction leading to cooperative learning and instant feedback. Thus, whole brain teaching combines direct instruction, sharing and immediate feedback (Tipton, 2016).

\section{REVIEWS ON WHOLE BRAIN TEACHING METHOD}

Teaching methods is considered as good if it implies relevant and visible training that will motivate students to learn, create an awareness to their understanding and encourage them to reflect on what they learn (Iurea., et al,2011). A good teaching method also helps students with their critical thinking skills and this will be the force which will drive them to be more creative and help them in problem solving. There are many teaching methods that can be used in a classroom worldwide. It depends on the effectiveness of the teacher to choose and adopt teaching methods that are suitable for a particular topic or a particular class in order to help students achieve their objectives. Research has demonstrated that engaging students in the learning process increases their attention and focus, motivates them to practice higher-level critical thinking skills and promotes meaningful learning experiences. Instructors who adopt a student-centered approach to instruction increase opportunities for student engagement, which then helps everyone more successfully, achieve the course's learning objectives (University of Washington). 
Whole brain teaching is a method of teaching which combines movement, making gestures, singing, dancing, teaching each other, group work and immediate feedback (Tripsa, 2014). In other words it is a method of teaching that tries to cater to all learning styles in one class. Research has documented that students learns best when the whole brain is involved (Boer, Steyn \& Toit , 2001). Understanding the working of the brain give opportunity to teachers to create an environment that provides students a higher chances for success in learning (Prince, Audrey, 2005).

Whole brain teaching develops a set of instruction which include different strategies to engage students by eliminating passive learning. It combines these instructional strategies of cooperative learning and direct instruction and the teacher plays the role of a facilitator where lessons are delivered one at a time (Arnold, 2015). Whole brain teaching is a research based instruction that gives more importance to interaction between teacher and students and also between students and students, it aslo delivers information to students in small doses. Kids practice what they learn with their classmate, using gestures to help them remember specific concepts. And while the students teach each other, the teacher walks around the room to see who understands the lesson and who needs more instruction. The process is viewed as more engaging for students. Whole brain teaching calls for students to be actively engaged in learning, and teachers to assign gestures to concept to help students remember them (Hoss, 2013; McCollum, 2013). The learning methods used in whole brain teaching helps to create a positive learning environment where students can actively participate in learning and hence create an effective long term learning (Arnold, 2015).

One of the strategies in Whole brain teaching is Teach-Ok and research says that when students teach to each other the memory of the students to retain information increases and the ability of each individual's will be able to retain up to $90 \%$ of the lesson learn after a 24 hours period (Arnold, 2015). Hosen (2015) conducted a research to check on the effect of whole brain teaching on academic outcomes of African elementary male students. He found out that in order to help students reach the desired learning outcome, educators are looking more towards brain based neuroscience research. Brain Research says that effective learning can take place when the whole brain is involved in learning. Interpreted in terms of Hermann's model, that for teaching and learning activities to be effective, all four brain quadrants should be included (Boer, Steyn \& Toit, 2001).

Whole brain teaching is a method developed to get students more attentive and focussed in class (Cape Gazette staff, 2012). According to recent research conducted by Clark, he concluded that whole brain teaching is a predictor of positive academic self concept (Clark, 2016) and also found out that it increases student's engagement in the classroom (Lindstorm, 2010; Cape Gazette staff, 2012). The Principal of Mission Crest elementary in Hesperia found out that the academic performance of the students was improved by 30 points on the 1000 point scale after using whole brain teaching method (Linstorm, 2010). Another teacher who has been teaching for 37 years and also who has been using whole brain teaching found out that kids enjoyed using the gestures and are happy with the mirroring technique and are found to have fun while learning. She also mentioned that she was very happy with mirroring since it helps her to know whether students are listening and learning or not and can give them instant feedback (McCollum, 2013; Tripsa, 2014).

Teach-Okay strategy helps students with their ability to retain the information, as studies reveal that when students teach to each other their ability to retain the information increases. Hence whole brain teaching creates active learners and effective long term memory. Another technique which is mirror words also proves to be very effective as it helps the teachers to be aware whether the students are listening or not (Carmen McCollum, 2013).

Teachers tries to find ways and means to upgrading themselves with new method of teaching on how to improve, and in this quest the teachers at Caloundra Christian College came across whole brain teaching and they are so impressed by the technique that they wanted to be well versed with this method of teaching (Sunshine coast daily, 2013). Whole brain teaching is based on using all parts of the brain, encouraging students to interact with their fellow students, respond, making gestures and offer immediate assessment and feedback. Whole brain teaching works for students of all learning styles and abilities ( Hoss, 2013; Ritchie, 2015). The other learning factors that brain based learning and whole brain teaching affects students learning are like it improves the retention power of the students, students has a positive attitude towards learning (INCI, N and Erte, H 2011, Annette Arnold 2015) and this positive attitude motivates students to have a positive attitude towards higher studies (Tufekci, S \& Demirel, M, 2009) and also improves composition writing skills of the students (Duman, 2006, Cape Gazette Newspaper, 2012).

\section{LIMITATIONS}


The connection between neuroscience and education is still a young field, there are still a lot of ongoing researches on the methods and technologies of cognitive science. Although, research indicates that connecting neuroscience to instructional practices has positive impact in closing the achievement gab of the students (VanHosen, 2015) it is however advisable to be cautious from the "neuroscientific myths" which may misinterpret scientific evidence. Research evidence from previous research that whole brain teaching is an effective method which helps to generate a high active classroom, effective classroom management and has a positive learning outcome but even though it was started in 1999, whole brain teaching has not reached the masses as much as other best practices around the nation (Tipton, 2016). Even though there is lack of research to support whole brain teaching technique, but the idea of making learning fun by combining classroom management and active learning and teaching is very interesting (Tipton, 2016). There is lack of prior research on whole brain teaching (Clark, 2016). This limitation is a reminder that further research regarding whole brain teaching is necessary.

\section{REFERENCE}

[1] Adunola, O. (2011). The Impact of teachers' teaching methods on the academic performance of primary school pupils in Ijebu-Ode local cut area of Ogun state. Ego booster books, Ogun State, Nigeria.

[2] Alford, D. (2014). What is whole brain teaching in the classroom. Walsh University article. Retrieved from http:/www.walsh.edu/whole-brain-teaching.

[3] Alaniz, A. 2015, Whole brain teaching and memory retention, Central elementary school, Portage township school. Retrieved from http://www.nwitimes.com/news/local/porter/portage/whole-brainteaching-and-memory- /article_c88d52bf-0c56-5bfb-a0fa-ac0486a9c45e.html

[4] Arnold, A. (2015), Whole Brain teaching and memory retention. The Times.nwi.com. Retrieved from http://www.nwitimes.com/news/local/porter/portage/whole-brain-teaching-and-memoryretention/article_c88d52bf-0c56-5bfb-a0fa-ac0486a9c45e.html

[5] Ayeni, A.J. (2011), " Teachers professional development and quality assurance in Nigerian Secondary Schools," World Journal of Education, 1(2): 143-149.

[6] Battle, J. (2010). Whole brain teaching: learning the way the brain is designed. Source: Teaching and learning. Retrieved from http://www.advanc-ed.org/source/whole-brain-teaching-learning-way-braindesigned.

[7] Bajak, A. (2014). Lectures aren't just boring, they're ineffective, too, study finds. Retrieved from http://www.sciencemag.org/news/2014/05/lectures-arent-just-boring-theyre-ineffective-too-study-finds

[8] Biffle, C. (2010). Whole brain teaching for challenging kids. Retrieved from http://www.wholebrainteaching.com/index.php?option=com_content\&view=article\&id=155\&Itemid=20 1

[9] Biffle, C. (2013). Whole Brain Teaching for challenging kids. Whole brain teaching: A world leader in brain based learning.p.7

[10] Biffle, C. (2014). C Research. $\quad$ Retrieved from http://www.wholebrainteaching.com/index.php?option=com_k2\&view=item\&id222:research\&Itemid=16 6

[11] Boer, A., Steyn, T., \& Toit, P.H. (2001). A whole brain approach to teaching and learning in higher education. South African Journal of Higher Education, 15(3), 185-93.

[12] Breakwell, G.M., Smith, J.A., \& Wright, D.B. (2012). Research methods in Psychology. $4^{\text {th }}$ edition. SAGE Publication Ltd. 165-166

[13] Brobeck, D.G., Digianantonio, A.J., \& Elia, M.J (n.d.). A meta-synthesis of WBT and active learning pedagogies: Faculty development, give brain power a boost. Handbook of research on professional development for quality teaching and learning. IGI global copyright. 84-90

[14] Canon, L. (2014). "Implementing whole class discussion in the seventh grade unit on ratios. Education and human development master's theses. 489

[15] Cape teachers learn to use their whole brains; Teaching method promotes learning. Cape Gazette Staff . (2012). Cape Town Newspaper.

[16] Clark H.W.S. (2016). Effect of whole brain teaching on student self-concept. Walden University Scholar Works. Walden dissertations and doctoral studies. 1-43.

[17] Dafford, S. (2004). The art of teaching well. New Straits Times Newspaper. Malaysia.

[18] Davis, H. M. (2007). Let them move: Kinesthetic learning and cognition. The Evergreen State College. Retrieve from http://archives.evergreen.edu/masterstheses/Accession89-

10MIT/Davis_H\%20MITthesis\%202007.pdf. 
[19] Duman, B. (2006). The effect of brain-based instruction to improve on students' academic achievement in social studies instruction. Retrieved from http://www.ineer.org/Events/ICEE2006/papers/3380.pdf.

[20] Duman, B. (2010). The effects of brain-based learning on the academic achievement of students with different learning styles. Retrieved from http://files.eric.ed.gov/fulltext/EJ919873.pdf

[21] Ganyaupfu, E.M. (2013). Teaching methods and students' academic performance. International journal of humanities and social science invention. 29-35.

[22] Heeter, S., \& Efird, N. (2014). Whole brain teaching retrieve from http://www.valdosta.edu/colleges/education/student-teaching-and-fieldexperiences/documents/professional-development/06.2014-powerpoint

[23] Herrmann, N. (2003). The whole brain business book. Tata McGraw-Hill Publishing Company Limited, New Delhi, 6-10.

[24] Hosen, W. (2015). The effect of whole brain teaching on the academic outcomes of African-American elementary male students. Journal of Cross-Disciplinary Perspectives in Education. 8(1). 52-56

[25] Hoss, Shelley. (2013). Teaching children well. Orange county register. California.

[26] Hruby, G.G., \& Goswami, U. (2011). Neuroscience and reading: A review for reading education researchers. Reading research quarterly, 46(2), 156-172.

[27] Inci, N., \& Erten, H. (2009). The Effect of Brain Based Learning on Academic Success, Attitude and Retrieval of Information in Science and Technology Classes. In ESERA conference, Lyon. 5- 9

[28] Iurea, C., Neacsu, I., Safta, C.G., \& Sudita, M. (2011), The study of the realtion between the teaching methods and the learning styles-The impact upon teh students' academic conduct. Procedia:Social and behavioural sciences, 256-260

[29] Jensen, E. (2005). Brain-based learning. Pearson Education, Inc., Indian Branch, 482 F.I.E. Patparganj, Delhi. 15.

[30] Jensen, E. (2009). Teaching with poverty in mind: What being poor does to kids' brains and what schools can do about it. Alexandria, VA: Association for Supervision and Curriculum Development.

[31] Jones, P. H. (2014). Neuroscience and education: A review of educational interventions and approaches informed by Neuroscience. Education Endowment Foundation. University of Bristol.

[32] Karami, M., Pakmehr, H., \& Aghili, A,(2012). Another view to importance of teaching methods in curriculum: collaborative learning and students' critical thinking disposition, Procedia:Social and Behavioural Sciences. 3266-3270.

[33] Lindstorm, N. (2010). Whole brain teaching commands students' attention: Funny gestures, chants spice up daily lessons. Daily press newspaper. California.

[34] McCollum, C. (2013). Teachers come from across the country for brain-training conference. The times newspaper. Indiana.

[35] Palasigue, J.T. (2009). Integrating Whole Brain Teaching Strategies to create a more engaged learning environment. Detroit, Michigan.

[36] Parirokh, M., \& Fattahi, R. (2005). A guide book for reviewing research literature, Tehran: Ketabdar;1617.

[37] Prince, Audrey (2005). Using the Principles of Brain-Based Learning in the Classroom: How to Help a Child Learn. Retrieved from https://www.superduperinc.com/handouts/pdf/81_brain.pdf.

[38] Porter, N. (2007). Get to know your brain. The times educational supplement.

[39] Ritchie, P. L. (2015). Whole brain teaching. Tampa Bay Times. Spring Hill.

[40] Serrao, A. (2007). Involving learners for better, holistic understanding. Newspaper.

[41] Siddiqui, S.V., Chatterjee, U., Kumar, D., Siddiqui, A., \& Goyal, N. (2008). Neuropsychology of prefrontal cortex. Indian Journal Psychiatry. 50(3). 202-208.

[42] Smith, S. (2007). Using action research to evaluate the use of brain based teaching strategies in the classroom. International Journal of Learning, 13(9), 121-126.

[43] Stewig, J. W., \& Moe, Alden J. (1972). Instructional strategies: Methods of increasing student participation in the classroom. National Council of Teachers of English. 9(7). 1112-1116.

[44] Taylor, L., \& Parsons, J. (2011). Improving Student Engagement. Current Issues in Education, 14(1). Retrieved from http://cie.asu.edu/

[45] Teacher tap into brain science to boost learning, pbs.orgnewshour. PBS Newshour, (2015).

[46] Teaching for the whole brain. Sunshine coast daily (2013). Newspaper.

[47] Tebabal, A., \& Kahssay, G. (2011). The effects of student-centered approach in improving students, graphical interpretation skills and conceptual understanding of kinematical motion. Lat. Am. J. Phy. Edu, 5(2): 374-381. 
[48] Tipton, A. (2016). Whole brain teaching-Best teaching practices retrieve from http://ashleytipton.weebly.com/whole-brain-teaching.html.

[49] Tripsa, M. (2014). Whole Brain Teaching. Techie Teachers’ Tricks.

[50] Tufekci, S., \& Demirel, M. (2009). " The effect of brain based learning on achievement, retention, attitude and learning process.” Elsevier publication. Procedia Social and Behavioral Sciences. 1782-1791.

[51] VanHosen, W. (2015). The effect of Whole Brain Teaching on the acacemic outcomes of AfricanAmerican elementary male students. Journal of Cross-Disciplinary Perspective in Education. 8(1), 5256.

[52] Varma, S., Mc Candliss, B.D., \& Schwartz, D.L. (2008) Scientific and pragmatic challenges for bridging education and neuroscience. American Educational Research .SAGE. Publication, Inc.,. 37(3). p.140-152

[53] Walbaum, S. (1989). Note-taking, Verbal aptitude, and listening span: Factors involved in learning from lectures. Paper presented at the annual meeting of the American Educational Research Association, San Francisco, CA.

[54] Willis, J. (2007). Brain-friendly strategies for the inclusion classroom. Association for supervision and curriculum development. USA. p.1-20. 